Article

\title{
Characteristics of Lightweight Concrete Based on a Synthetic Polymer Foaming Agent
}

\author{
Marta Kadela ${ }^{1, *(\mathbb{D}}$, Alfred Kukiełka ${ }^{1}(\mathbb{D})$ and Marcin Małek ${ }^{2} \mathbb{C}$ \\ 1 Building Research Institute (ITB), ul. Filtrowa 1, 00-611 Warsaw, Poland; a.kukielka@itb.pl \\ 2 Faculty of Civil Engineering and Geodesy, Military University of Technology, ul. Gen. Sylwestra Kaliskiego 2, \\ 01-476 Warsaw, Poland; marcin.malek@wat.edu.pl \\ * Correspondence: m.kadela@itb.pl; Tel.: +48-603-60-12-48
}

Received: 28 September 2020; Accepted: 3 November 2020; Published: 5 November 2020

check for updates

\begin{abstract}
The components of foamed concrete have a significant effect on its properties. Protein-based foamed concrete is used much more often. This study aims to assess the properties of foamed concrete with a density of around $500,700,800$ and $1000 \mathrm{~kg} / \mathrm{m}^{3}$ formed by using a synthetic polymer-based foaming agent. The distribution of pores, wet and dry density and compressive strengths were evaluated. In addition, the creep deformations of foamed concrete with different densities were measured. The difference in density of up to $170 \mathrm{~kg} / \mathrm{m}^{3}$ for the highest densities was obtained. Foamed concrete with higher densities $\left(700\right.$ and $800 \mathrm{~kg} / \mathrm{m}^{3}$ ) showed similar characteristics of pores, which were different from those of samples with a density of $500 \mathrm{~kg} / \mathrm{m}^{3}$. Compressive strength equal to $5.9 \pm 0.2,5.1 \pm 0.2,3.8 \pm 0.3$ and $1.4 \pm 0.2 \mathrm{MPa}$ was obtained for foamed concrete with a density of $500,700,800$ and $1000 \mathrm{~kg} / \mathrm{m}^{3}$, respectively. The obtained compressive strengths were higher than those found in the literature for the foamed concrete with the same densities. With increasing density, smaller creep deformations were obtained. Creep deformations were 509, 495 and $455 \mu \varepsilon$ for samples with densities of around 500, 700 and $1000 \mathrm{~kg} / \mathrm{m}^{3}$ respectively. Deformation under long-term loading took place up to 90 days, regardless of the density of the foamed concrete.
\end{abstract}

Keywords: foamed concrete; lightweight cellular concrete; pore material; synthetic foaming agent; prepared foam; mechanical properties; density; air-void structure; compressive strength; creep

\section{Introduction}

Due to sustainable development and the related reduction in energy consumption and $\mathrm{CO}_{2}$ emission [1-6], lightweight concrete, aerated concrete and foamed concrete are increasingly used $[7,8]$. Foamed concrete (FC) is classified as lightweight concrete with a density ranging from 280 to $1800 \mathrm{~kg} / \mathrm{m}^{3}$ [9-11]) and with a minimum of $20 \%$ of air pore volume in the cementitious mix [12,13]. Foamed concrete was made using the pre-foaming method with physical foaming or mixing and the foaming method with chemical foaming [14-16]. Foamed concrete is characterized by its ability to flow, self-compact and self-level as well excellent thermal and acoustic insulation [17-20]. The compressive strength ranges from 0.21 to $10.34 \mathrm{MPa}$ for a density of 300 to $1600 \mathrm{~kg} / \mathrm{m}^{3}$ [8,21-23], which is related to its typical application [24-26]. In recent years, the development of foamed concrete has been observed. Amran et al. [27], Fadila et al. [28], Kang [29], Fernando et al. [30] and Portal et al. [31] produced foamed concrete for use in wall panels. Rum et al. [32] used foamed concrete as a component in a profiled composite slab. Kadela et al. [33-35], Drusa et al. [36-38], Tian et al. [39] and Lee at al. [40] used foamed concrete in a pavement or floor structure to transmit a load on a subsoil, including weak soil. Moreover, foamed concrete has been used in building foundations [20,41]. In addition, foamed concrete has the potential to become a mainstream material that uses waste material successfully as a replacement for cement or fine aggregate [42-44]. 
The components of foamed concrete (type of cement [45-47], water [48,49], water/binder ratio [50-52], additives [53,54] and admixtures [55-57]) have a significant effect on its properties [58-60]. Even foamed concrete with a compressive strength of $70 \mathrm{MPa}$ can be made by the addition of polypropylene fiber and fine silica fume and used in high-performance cement [61]. However, an important role in the performance of foamed concrete is played by the foaming agent, which is used to make foam and then form enclosed pores [62]. Foaming agents can be classified into two groups, synthetic- and natural-based foaming agents [63], or five categories: rosin, synthetic, protein, composite and the latest type [64-66]. Some foaming agents are polymer admixtures [22,67]. In this context, foamed concrete is a special type of polymer-cement concrete [68-70]. Synthetic foaming agents are amphiprotic substances that are strongly hydrophilic and easily dissolve in water, yielding air bubbles [71]. The synthetic agent reduces the surface tension of the solution, which increases the stability of air bubbles. However, when adding a synthetic agent into a complex chemical environment such as concrete, the compatibility of surfactant and cement particles is critical to effectively entrain the desired air content and microstructure of concrete [71]. This may be the reason that the foamed concrete based on a protein foaming agent is used much more often [72-74]. In this case, air bubbles are caused by protein degradation. When the peptide linkage of large protein molecules breaks, more hydrophobic small molecules are formed. Similar to a synthetic blowing agent, this process reduces the surface tension of the solution and creates an interface to the air bubbles. The protein foam resulted in smaller isolated spherical air bubbles compared to air voids produced with synthetic foam [71]. This may result in over $80 \%$ higher compressive strength for protein-based foaming agents than for synthetic-based ones [13]. Moreover, Falliano et al. [65] obtained much higher compressive strength of foamed concretes with a density of around 400 to $850 \mathrm{~kg} / \mathrm{m}^{3}$ for a protein-based foaming agent than for a synthetic-based foaming agent. This impact was far more pronounced than that observed by Panesar [71] on medium-to-high density foamed concrete. Meanwhile, Sun et al. [75] obtained around $43 \%$ and $11 \%$ higher compressive strength for synthetic-based foamed concrete compared to organic-based foamed concrete made from plant and animal glue/blood, respectively. Moreover, foamed concrete produced on the basis of a synthetic foaming agent is rarely found in the literature. Therefore, this study aims to assess the properties of hardened foamed concrete with a low density of around $500,700,800$ and $1000 \mathrm{~kg} / \mathrm{m}^{3}$ formed by using a synthetic polymer-based foaming agent. Evaluation of the foamed concrete was carried out to examine the distribution of pores and properties such as wet and dry density and compressive strength. In addition, unlike other scientists, we measured the creep deformations of foamed concrete with different densities. Assessment of behavior under long-term load is very important for structures such as roads or car park pavements, floor structures or building foundations, where foamed concrete is currently used, as mentioned above.

\section{Materials}

\subsection{Specimen Preparation}

The materials used in this study were Portland cement (Górażdże Cement S.A., Chorula, Poland), tap water and foaming agent. The industrial Portland cement was CEM I 42.5R, according to PN-EN 197-1:2012. Its chemical composition measured as per PN-EN 196-2:2013-11 (LOI-loss on ignition; IR-insoluble residue) and physical properties measured according to PN-EN 196-6:2011 are given in Tables 1 and 2 respectively. The compressive strength of cement was determined according to PN-EN 196-1:2016-07. The phase composition was calculated according to Bogue's formula.

Table 1. Chemical and phase composition of cement.

\begin{tabular}{|c|c|c|c|c|c|c|c|c|c|c|c|}
\hline Chemical & $\mathrm{SiO}_{2}$ & $\mathrm{Al}_{2} \mathrm{O}_{3}$ & $\mathrm{Fe}_{2} \mathrm{O}_{3}$ & $\mathrm{CaO}$ & $\mathrm{MgO}$ & $\mathrm{SO}_{3}$ & $\mathrm{Na}_{2} \mathrm{O}$ & $\mathrm{K}_{2} \mathrm{O}$ & $\mathrm{Cl}$ & LOI & IR \\
\hline Unit (vol. \%) & 19.5 & 4.9 & 2.9 & 63.3 & 1.3 & 2.8 & 0.1 & 0.9 & 0.05 & 2.48 & 0.63 \\
\hline Phase & \multicolumn{2}{|c|}{ C3S } & \multicolumn{3}{|c|}{$\mathrm{C} 2 \mathrm{~S}$} & \multicolumn{3}{|c|}{ C3A } & \multicolumn{3}{|c|}{ C4AF } \\
\hline Unit (vol. \%) & \multicolumn{2}{|c|}{68} & \multicolumn{3}{|c|}{4} & \multicolumn{3}{|c|}{8} & \multicolumn{3}{|c|}{9} \\
\hline
\end{tabular}


Table 2. Physical properties of cement.

\begin{tabular}{|c|c|c|c|}
\hline \multirow{2}{*}{$\begin{array}{l}\text { Specific Surface Area } \\
\qquad\left(\mathrm{m}^{2} / \mathrm{kg}\right)\end{array}$} & \multirow{2}{*}{$\begin{array}{l}\text { Specific Gravity } \\
\left(\mathrm{kg} / \mathrm{m}^{3}\right)\end{array}$} & \multicolumn{2}{|c|}{ Compressive Strength after Days (MPa) } \\
\hline & & 2 Days & 28 Days \\
\hline 3840 & 3060 & 28.0 & 58.0 \\
\hline
\end{tabular}

A commercial liquid polymer admixture with specific gravity of $1.02 \mathrm{~g} / \mathrm{cm}^{3}$ was used as foaming agent. The FTIR spectra of the foaming agent are shown in Figure 1.

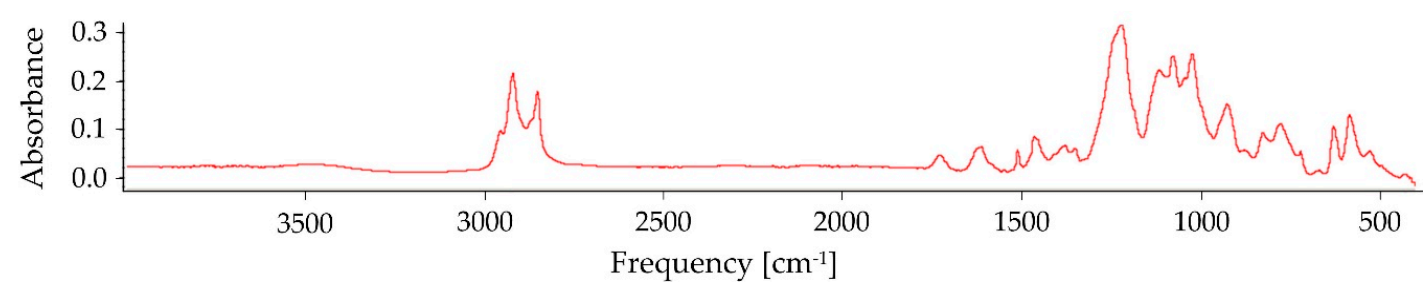

Figure 1. FTIR spectra of foaming agent (stearyl dimethylethylammonium methosulfate).

\subsection{Mix Composition}

The specimens of foamed concrete with four different densities were produced to investigate the effect of synthetic polymer foaming agent on the properties of foamed cementitious mix (Table 3). The densities of hardened foamed concrete were around 500, 700, 800 and $1000 \mathrm{~kg} / \mathrm{m}^{3}$ with a tolerance of $\pm 50 \mathrm{~kg} / \mathrm{m}^{3}$, marked as FC500, FC700, FC800 and FC1000, respectively. The synthetic foaming agent (MEEX, Chrzanów, Poland) contents were 8.0, 6.0, 5.0 and $4.0 \mathrm{dm}^{3}$ per $100 \mathrm{~kg}$ of cement. As reported in Table 3, the constant $w_{\text {eff }} / c$ ratio was fixed equal to 0.44 for all specimens, where $w_{\text {eff }}$ is water content, which includes tap water and liquid foaming agent; $c$ is the cement content. This was based on the results of Jones and McCarthy [26], Xianjun et al. [76] and the authors' earlier experiments [77-79].

Table 3. Mix proportions $\left(1 \mathrm{~m}^{3}\right)$.

\begin{tabular}{|c|c|c|c|c|c|}
\hline Mix Symbol & $\begin{array}{c}\text { Cement } \\
(\mathrm{kg})\end{array}$ & $w_{e f f} / c$ & $\begin{array}{l}\text { Water } \\
(\mathbf{k g})\end{array}$ & $\begin{array}{c}\text { Foaming Agent } \\
\left(\mathrm{dm}^{3} \text { per } 100 \mathrm{~kg} \text { of cement) }\right.\end{array}$ & $\begin{array}{c}\text { Foaming Agent } \\
\left(\mathrm{dm}^{3}\right)\end{array}$ \\
\hline FC500 & 430 & \multirow{4}{*}{0.44} & 155 & 8.0 & 34.4 \\
\hline FC700 & 530 & & 201 & 6.0 & 31.8 \\
\hline FC800 & 610 & & 238 & 5.0 & 30.5 \\
\hline FC1000 & 700 & & 280 & 4.0 & 28.0 \\
\hline
\end{tabular}

\subsection{Mix Production}

The foamed concrete specimens were prepared with the pre-forming method. First, water and cement were mixed, and in the next step, the foam was added and all components were mixed (Figure 2a). In order to make a stable foam with density of $50 \pm 3 \mathrm{~kg} / \mathrm{m}^{3}$, the appropriate amount of liquid polymer agent was pressurized with air at approximately 5 bars using a foam generator. The foam content was established on the basis of the target dry density (considering earlier experiments); see Table 3 . A tolerance of $50 \mathrm{~kg} / \mathrm{m}^{3}$ was allowed on the achieved dry density. The entire manufacturing process of foamed concrete must carefully consider the densities of the mix, the foaming production rate and other factors in order to prepare high-quality foamed concrete. The key factors in producing stable foamed concrete included the pressurizing of the foaming agent at stable pressure and mixing the components in constant rotational speed. 

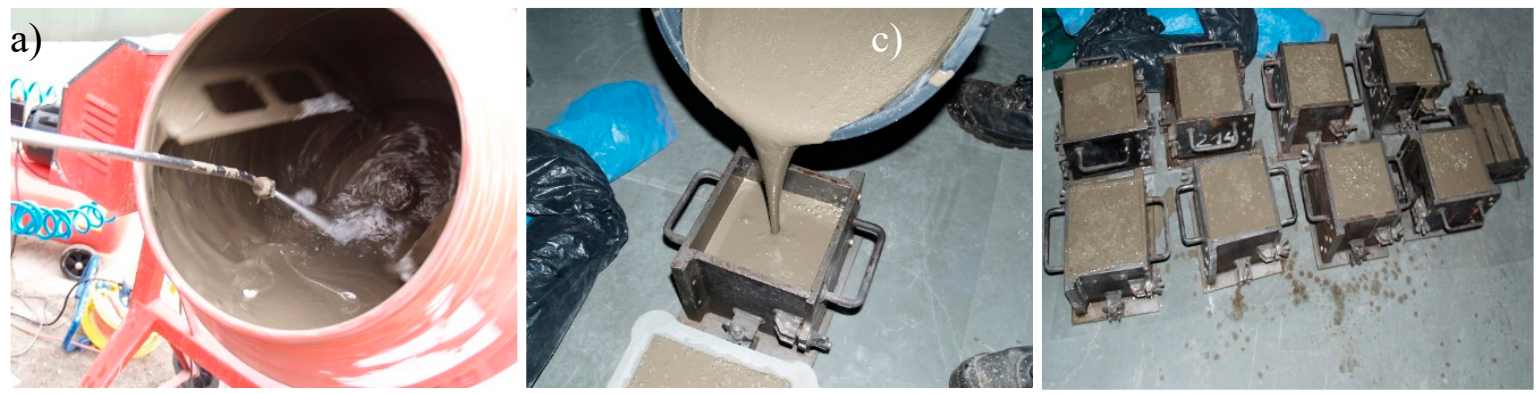

Figure 2. Preparation of samples: (a) adding foam; (b) pouring the mixture; (c) storage of samples.

All specimens were poured into steel molds (Figure $2 b, c$ ) and were covered with cellophane to protect against water evaporation and to ensure the best bonding conditions [65] in a curing room at $20 \pm 1{ }^{\circ} \mathrm{C}$ for $24 \mathrm{~h}$. Subsequently, the samples were removed from the molds and stored in a curing room at $20 \pm 1{ }^{\circ} \mathrm{C}$ and $95 \%$ humidity for 14 days. After this time, the foamed concrete samples were stored under ambient conditions (at $20 \pm 1^{\circ} \mathrm{C}$ and $60 \pm 10 \%$ humidity).

\section{Methodology}

\subsection{General Information}

The tests on hardened concrete were carried out after 28 days of curing. The material (density and distribution of pores) and mechanical properties of the concrete (compressive strength and creep deformation) were tested. Because foamed concrete is a relatively new material, there are no test standards for it in Poland or any other country [80].

\subsection{Density}

The density of the mixture was measured as per PN-EN 12350-6:2011 after pouring the mixture into the mold. The six specimens for each mix were measured.

The density of hardened foamed concrete was measured with $150 \mathrm{~mm} \times 150 \mathrm{~mm} \times 150 \mathrm{~mm}$ standard cubes as per PN-EN 12390-7:2011. The as-received specimen, i.e., naturally dried samples, was assessed. Ten measured specimens for each mix were tested.

\subsection{Distribution of Pores}

The distribution of air bubbles in the foamed concrete was analyzed using a LM microscope (OPTA-TECH STX12, Opta-Tech, Warsaw, Poland).

\subsection{Compressive Strength}

Compressive strength was measured on samples $150 \mathrm{~mm} \times 150 \mathrm{~mm} \times 150 \mathrm{~mm}$, according to PN-EN 12390-3:2011 + AC:2012, using a compression machine MEGA 6-3000-100 (FORM+TEST, Riedlingen, Germany) having $3000 \mathrm{kN}$ as max. load capacity. The loading rate was assumed as per PN-EN 772-1 + A1:2015-10 as for cellular concrete masonry units. Three samples per mix were used.

\subsection{Creep Deformation}

The creep test was carried out on beams $150 \mathrm{~mm} \times 150 \mathrm{~mm} \times 450 \mathrm{~mm}$ using a concrete creep testing machine (A-Grotex Sp. z o.o., Gliwice, Poland) in a room at $20 \pm 1{ }^{\circ} \mathrm{C}$. The load was applied continuously to the level of $1 / 3$ of the compressive strength. For this purpose, the average compressive strength was determined on three vertically oriented base samples; see Section 3.4. Readings from measuring instruments were made at levels $1 / 3$ and $2 / 3$ of the specified strength. Five minutes post loading, the first strain reading was taken, recognized as an immediate strain. Then, regular readings of the total strain of the sample were carried out over a period of 1 year according to the following 
scheme: daily during the first week, once a week for 3 months and once a month for the rest of the period. The creep deformation after a specified time was determined by Equation (1). Four specimens per mix were used.

$$
\varepsilon_{c}(t)=\varepsilon_{t o t}(t)-\varepsilon_{s}(t)-\varepsilon_{a}
$$

where:

$\varepsilon_{c}(t)$-creep deformation in time $t$;

$\varepsilon_{\text {tot }}(t)$ - total measured creep deformation of foamed concrete sample long-term loading in time $t$;

$\varepsilon_{a}$-immediate strain determined after 5 min of obtaining $1 / 3$ of compressive strength;

$\varepsilon_{S}(t)$-shrinkage in time $t$.

Therefore, at the same time as the start of the long-term loading of samples, the next three samples of $150 \mathrm{~mm} \times 150 \mathrm{~mm} \times 450 \mathrm{~mm}$ were tested in the shrinkage test using Amsler's apparatus (EMEL, Warsaw, Poland). The initial distance between the measuring points on the sample was determined. Subsequently, the samples were stored in a curing room at $20 \pm 2{ }^{\circ} \mathrm{C}$ and $50 \pm 3 \%$ humidity, and the distance between the measuring points on the sample was measured.

The shrinkage was determined by Equation (2). Three specimens for each density were tested.

$$
\varepsilon_{s}=\frac{l_{0}-l_{t, i}}{l_{0}}
$$

where:

$\varepsilon_{s}$-shrinkage in $i$-period;

$l_{0}, l_{t}$-initial distance between measuring points and distance after a specified curing time.

\section{Results and Discussion}

\subsection{Density}

Figure 3 presents the results of average densities of the mixture and hardened sample. The density of hardened foamed concrete was $970 \pm 30,800 \pm 30,720 \pm 20$ and $550 \pm 20 \mathrm{~kg} / \mathrm{m}^{3}$ for foaming agent content of 4.0, 5.0, 6.0 and $8.0 \mathrm{dm}^{3}$ per $100 \mathrm{~kg}$ of cement, respectively. The volume of foam commonly created air-voids and resulted in lower density [8]. The density of the mixture was $1100 \pm 30,820 \pm 30$, $740 \pm 20$ and $550 \pm 20 \mathrm{~kg} / \mathrm{m}^{3}$. On the basis of the achieved results, it was observed that the densities of the hardened sample from one batch of the mix were obtained with a standard deviation of $\pm 30 \mathrm{~kg} / \mathrm{m}^{3}$ and with tolerance at $\pm 50 \mathrm{~kg} / \mathrm{m}^{3}$ of the target value. This is in line with the practical method used in industrial concrete production $[65,72]$. The most acceptable tolerance for the density of the hardened sample is limited to $\pm 50 \mathrm{~kg} / \mathrm{m}^{3}$, which might reach a difference of up to $\pm 100 \mathrm{~kg} / \mathrm{m}^{3}$ for high density [8].

The densities of the mixture and hardened samples decreased with the increase in foaming agent content [81]. These relationships were exponential. The differences between the density of the mixture and hardened sample were from 0 (this value is based on the standard deviation) to $170 \mathrm{~kg} / \mathrm{m}^{3}$ depending on the density of foamed concrete. Larger differences were demonstrated for higher densities; see Figure 3. This is due to the higher air content and the lower cement material content for lower density samples. The same trend was observed by Falliano et al. [65], who obtained a difference between the density of the mixture and hardened sample of around 40 to $80 \mathrm{~kg} / \mathrm{m}^{3}$ for synthetic-based foamed concrete, with density in the range of 400 to $800 \mathrm{~kg} / \mathrm{m}^{3}$ and 40 to $100 \mathrm{~kg} / \mathrm{m}^{3}$ for protein-based foamed concrete. Figure 4 presents the ratio of difference between density of the mixture and hardened sample to density of hardened foamed concrete. The results in this study were compared with those obtained by Falliano et al for other foaming agents (protein and synthetic) [65]. 


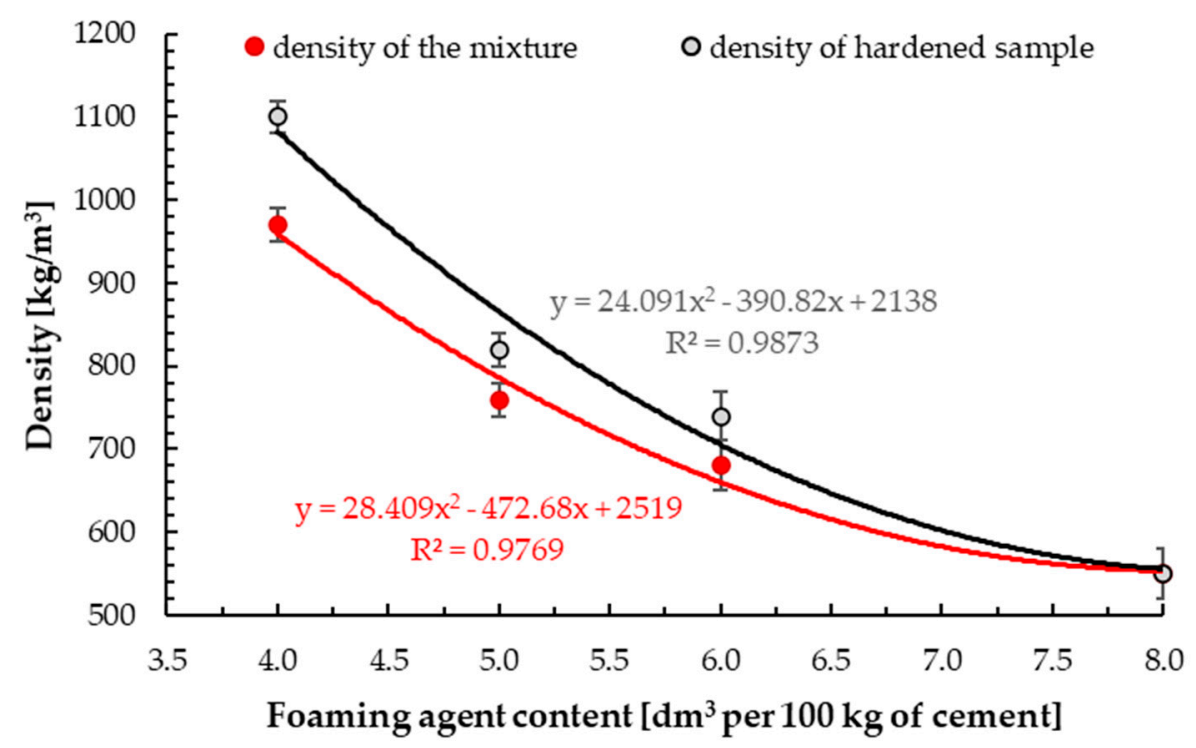

Figure 3. Density of the mixture and hardened samples with different content of foaming agent.

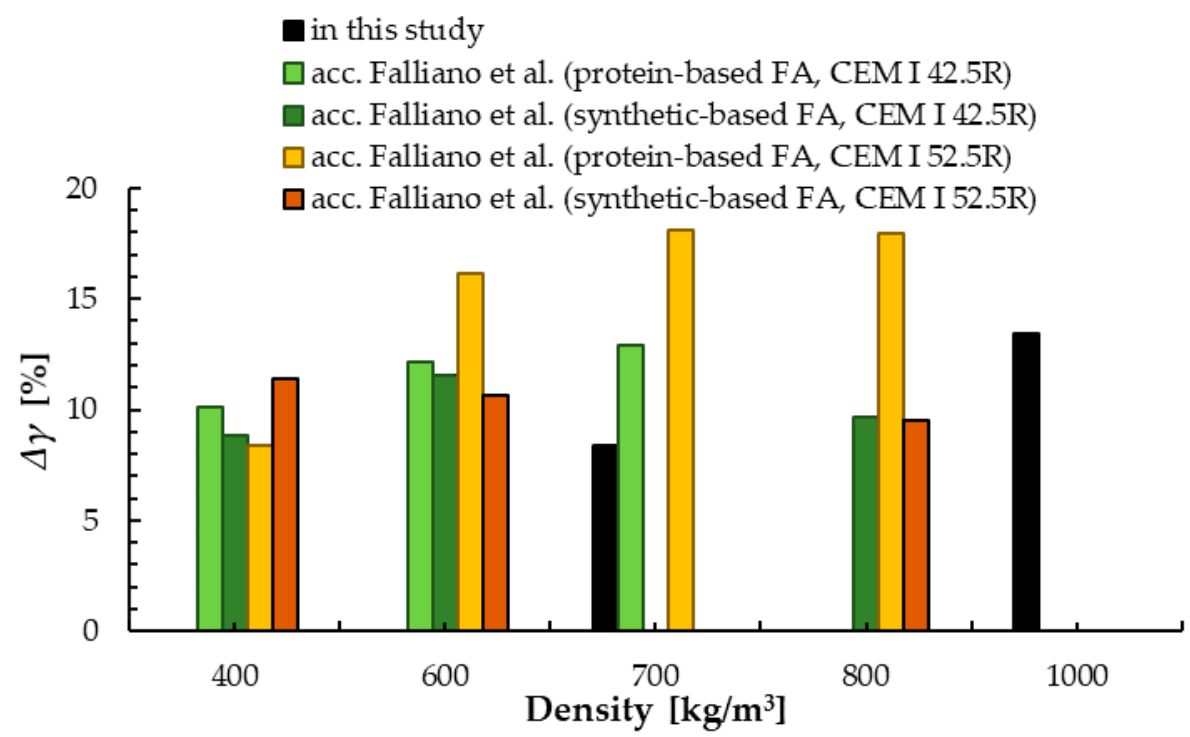

Figure 4. Ratio of difference between the density of the mixture and hardened foamed concrete to the density of hardened samples $\Delta \gamma$ depending on density.

\subsection{Distribution of Pores}

The decrease in density with increasing of the foaming agent content is associated with the change in the air-void structure of foamed concretes; see Figure 5. Foamed concrete is a lightweight construction material with a highly porous microstructure for all obtained densities. It can be observed that the density of foamed concrete increased with the decrease in pore size. Moreover, sometimes, larger pores were present (Figure $5 b$ ), but in general, the air-voids were quite uniformly distributed throughout the matrices [22].

Based on Figures $5 b$ and $6 a$, and analogously, Figures $5 c$ and $6 b$ (except the area with large pores), it can be observed that the samples of 700 and $800 \mathrm{~kg} / \mathrm{m}^{3}$ density (FC700 and FC800, respectively) had similar characteristics of pores, such as number, area, perimeter and shape descriptors (circularity, roundness and solidity). The size of the pores ranged from 0.26 to even $3.45 \mathrm{~mm}$ for foamed concrete with a density of $700 \mathrm{~kg} / \mathrm{m}^{3}$. This was not the case in samples with a density of $500 \mathrm{~kg} / \mathrm{m}^{3}$; see Figure $5 \mathrm{a}$. The number of air-voids for foamed concrete with the lowest density (FC500) was greater and the 
average thickness of the air bubbles wall was thinner than for the other two tested densities (FC700 and FC800). Moreover, pores of samples with density of $500 \mathrm{~kg} / \mathrm{m}^{3}$ were more circular and round. The average size of pores ranged from 0.43 to $0.65 \mathrm{~mm}$. The same size of pores was determined by Zhu et al. [62] for anionic surfactant as a foaming agent. Samples with a density of around 700 and $800 \mathrm{~kg} / \mathrm{m}^{3}$ had smaller air-voids. This is consistent with the observation that smaller size of pores corresponds to higher density [9]. For example, Wan et al. [82] obtained air-voids between 0.010 and $0.150 \mathrm{~mm}$ in diameter for foamed concrete with a density of $1500 \mathrm{~kg} / \mathrm{m}^{3}$; Hilal et al. [14] achieved between approximately 0.02 and $2 \mathrm{~mm}$ for foamed concrete with nominal densities of 1300 , 1600 and $1900 \mathrm{~kg} / \mathrm{m}^{3}$; and Sun et al. [75] obtained air-voids of $0.517 \mathrm{~mm}$ for foamed concrete with a density of $600 \mathrm{~kg} / \mathrm{m}^{3}$. At the same time, more large air bubbles of up to $3.5 \mathrm{~mm}$ in diameter were observed in higher densities; see Figure 6. These observations were analogous to the results of foamed concrete obtained by other scientists [22,80]. In addition, according to Sun et al. [75], air-void walls in synthetic-based foamed concrete are much thicker and pore sizes are smaller and less connected than those of protein-based foamed concrete.

a)

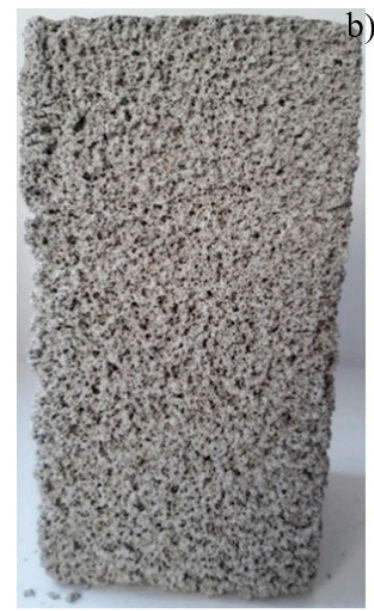

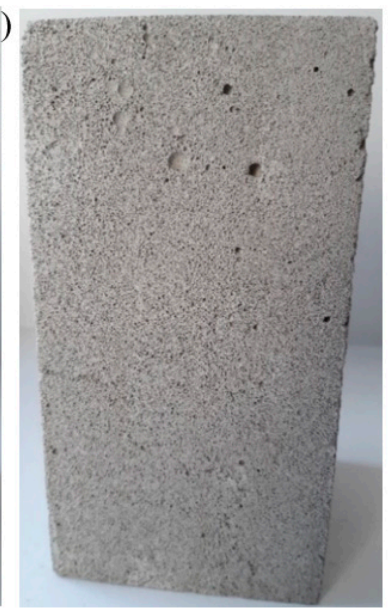

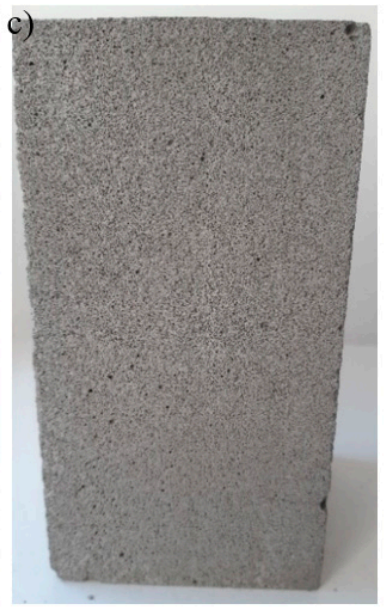

Figure 5. Size and distribution of pores in hardened foamed concrete samples with different densities: (a) $500 \mathrm{~kg} / \mathrm{m}^{3}$ (FC500), (b) $700 \mathrm{~kg} / \mathrm{m}^{3}$ (FC700), (c) $800 \mathrm{~kg} / \mathrm{m}^{3}$ (FC800).

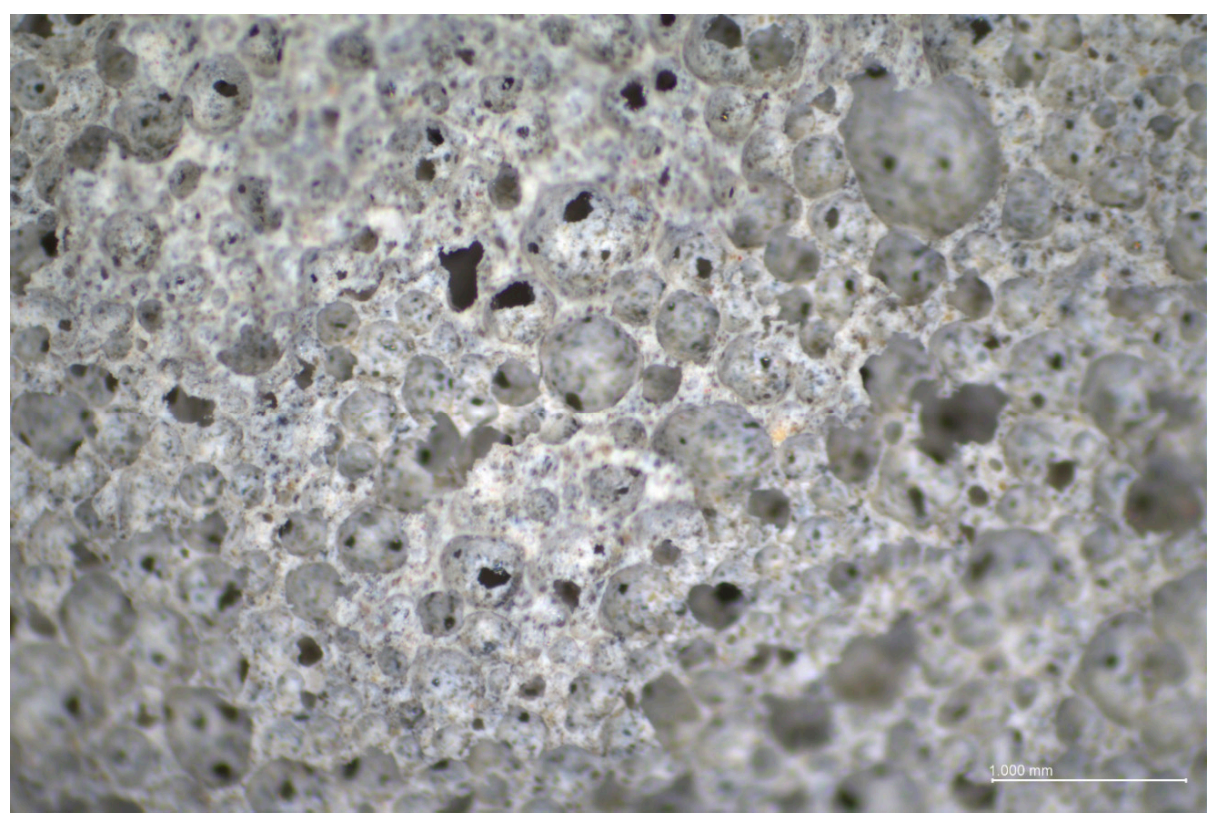

(a)

Figure 6. Cont. 


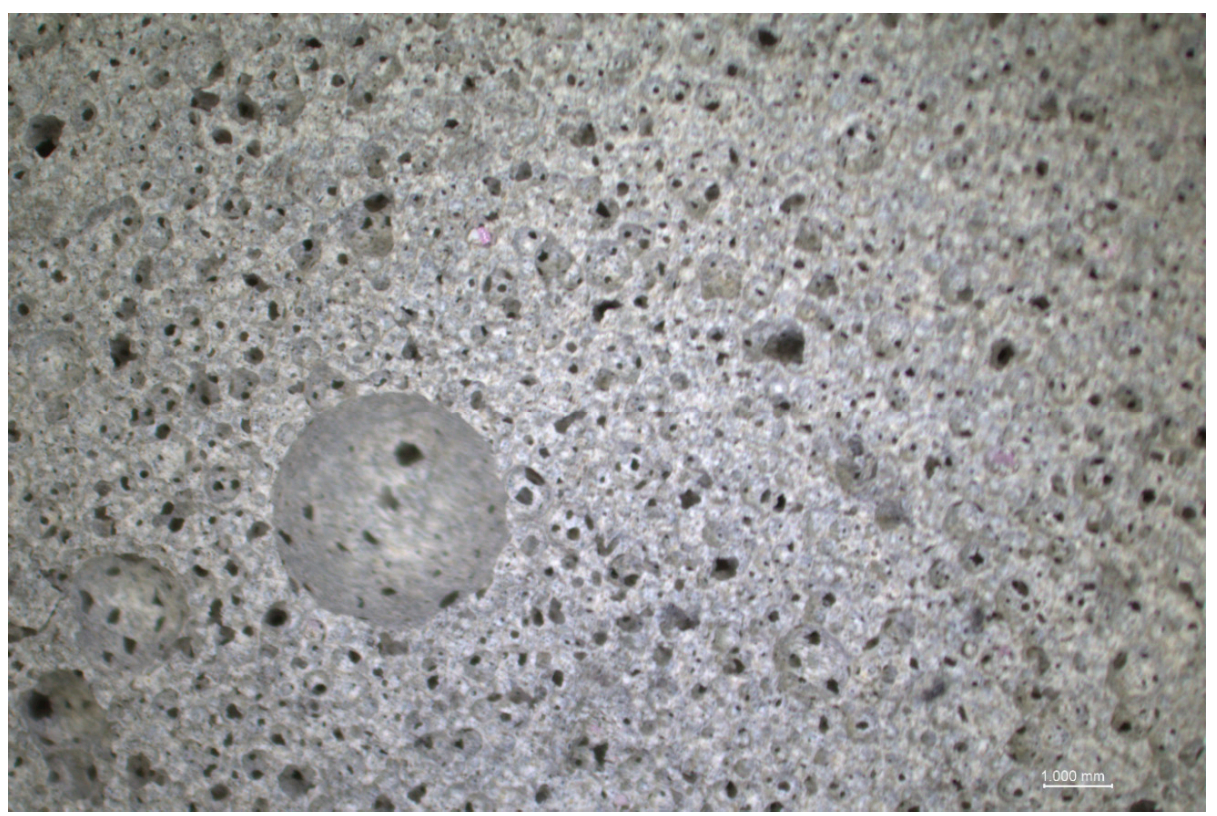

(b)

Figure 6. Light microscopy image of hardened foamed concrete samples with density of around (a) $800 \mathrm{~kg} / \mathrm{m}^{3}$, (b) $700 \mathrm{~kg} / \mathrm{m}^{3}$.

\subsection{Compressive Strength}

The results of compressive strength for samples with different densities are shown in Figure 7. Compressive strength is directly related with density [8]. It was observed that with the increase in density, compressive strength also increased [8,9]. With the addition of foaming agent of 4.0, 5.0, 6.0 and $8.0 \mathrm{dm}^{3}$ per $100 \mathrm{~kg}$ of cement, the 28-day compressive strength was equal to $5.9 \pm 0.2,5.1 \pm 0.2$, $3.8 \pm 0.3$ and $1.4 \pm 0.2 \mathrm{MPa}$, respectively. The addition of foaming agent decreased compressive strength because the volume of foam created pores and resulted in lower density.

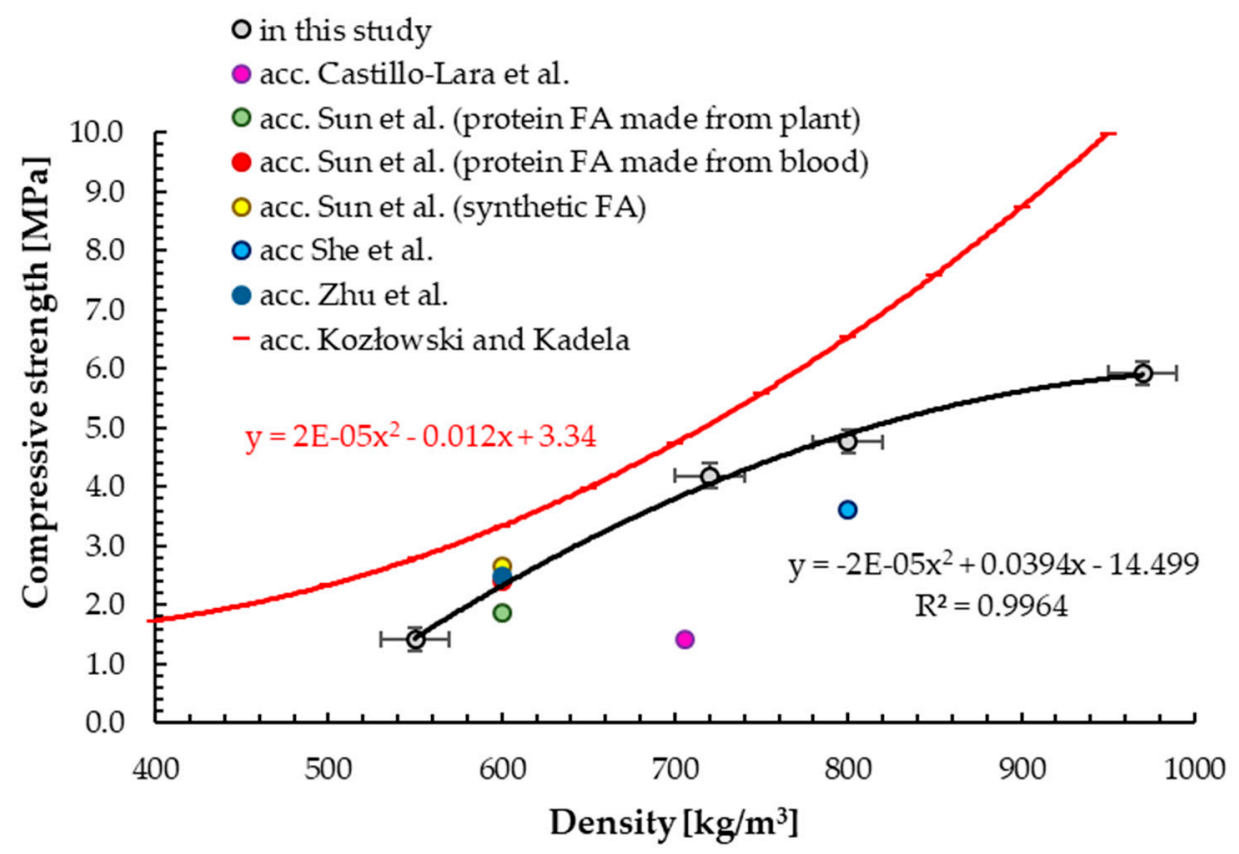

Figure 7. Relationship between density and compressive strength of hardened foamed concrete. 
The correlation between density of hardened foamed concrete and its compressive strength is exponential, which is in line with observations made by other scientists [8,59].

The results obtained in this study showed that the compressive strengths were higher than the results achieved by other scientists for the same densities, but lower than in the authors' previous research [59], marked with the red line in Figure 7. Namely, a correlation was obtained for foamed concrete with a target density from 400 to $1400 \mathrm{~kg} / \mathrm{m}^{3}$. The compressive strength obtained for higher densities influences the shape of the approximation curve. Moreover, despite the fact that the values were higher than in this study, the dispersion of the obtained results was greater. The presented diagram confirms that, depending on many factors (e.g., foam addition pressure, which was different in these tests), the obtained results may be different. This is also confirmed by the results of other scientists; e.g., Castillo-Lara et al. [83] obtained 1.42 $\pm 0.05 \mathrm{MPa}$ for foamed concrete with density of $706 \pm 8 \mathrm{~kg} / \mathrm{m}^{3}$. Meanwhile, She et al. [67] achieved $3.61 \mathrm{MPa}$ for foamed concrete with $800 \mathrm{~kg} / \mathrm{m}^{3}$. This is due to the good structure of the foam (homogeneity of the bubbles) and its properties [80]. In addition, the synthetic foaming agent contains a stabilizer such as nanoparticles, which may accumulate at the interface of the air bubbles [67] to prevent collapse. High stability and strength of the foam will be beneficial to maintain the foam structure in the cement paste [84] and thus result in higher compressive strength. Around $43 \%$ higher compressive strength compared to plain foamed concrete (3.61 MPa) with a density of $800 \mathrm{~kg} / \mathrm{m}^{3}$ was determined by using an organic stabilizer or $81 \%$ when nano-silica was used additionally [67]. Moreover, with the addition of $0.5 \%$ concentration of xanthan gum to commercial anionic surfactant foaming agents, around $48.5 \%$ higher compressive strength ( $3.58 \mathrm{MPa})$ compared to a reference sample of foamed concrete with a dry density of around $600 \mathrm{~kg} / \mathrm{m}^{3}$ was obtained [62]. In addition, the thickness of air-void walls was doubled.

Images showing the failure of foamed concrete samples with different densities are presented in Figure 8. The comparison image was obtained by Castillo-Lara et al. [83] for unreinforced foamed concrete with $706 \mathrm{~kg} / \mathrm{m}^{3}$ density. Brittle behavior of foamed concrete specimens with higher density can be observed.

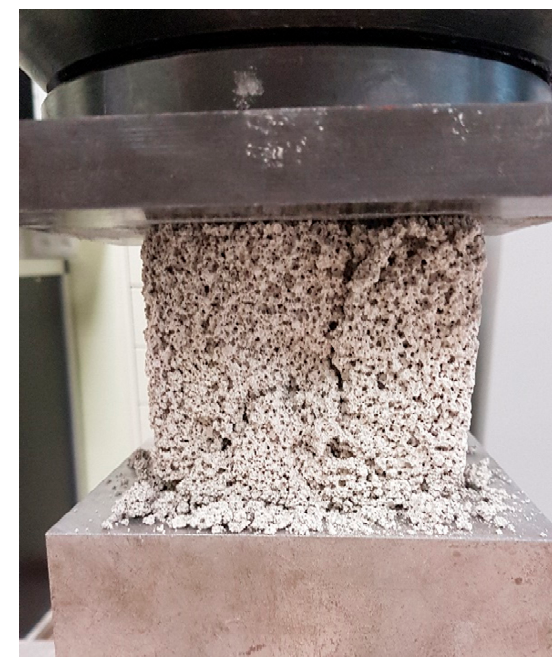

(a)

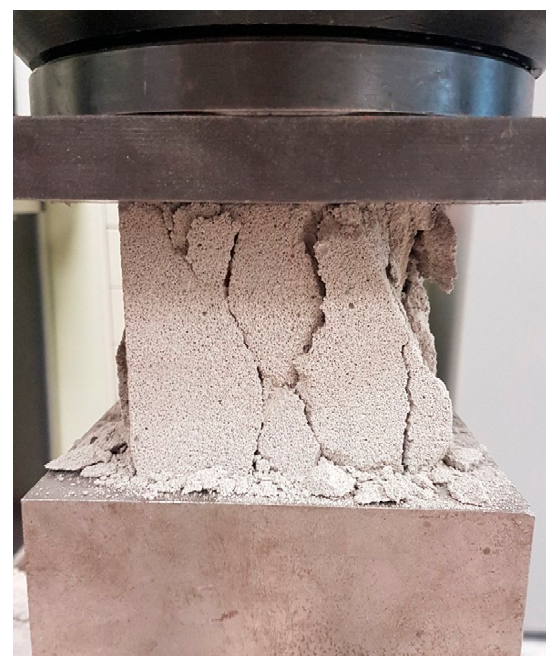

(b)

Figure 8. Image of destruction of foamed concrete with density of around: (a) $500 \mathrm{~kg} / \mathrm{m}^{3}$, (b) $700 \mathrm{~kg} / \mathrm{m}^{3}$.

\subsection{Creep Deformation}

The results of long-term loading of foamed concrete samples with different densities are shown in Figure 9a. It can be observed that for specimens with higher densities, creep deformations were smaller. Creep deformations were equal to 509,495 and $455 \mu \varepsilon$ for foamed concrete with a density of around 500,700 and $1000 \mathrm{~kg} / \mathrm{m}^{3}$, respectively. Deformation under long-term loading took place up to 90 days, regardless of the density of foamed concrete. After 90 days, the differences in the values in two consecutive measurements were less than $0.2 \%$, and therefore the creep process was considered 
complete. For foamed concrete with a density of around 700 and $1000 \mathrm{~kg} / \mathrm{m}^{3}$, around $2.6 \%$ and $10.6 \%$ decrease compared to samples with density of $500 \mathrm{~kg} / \mathrm{m}^{3}$ were obtained.
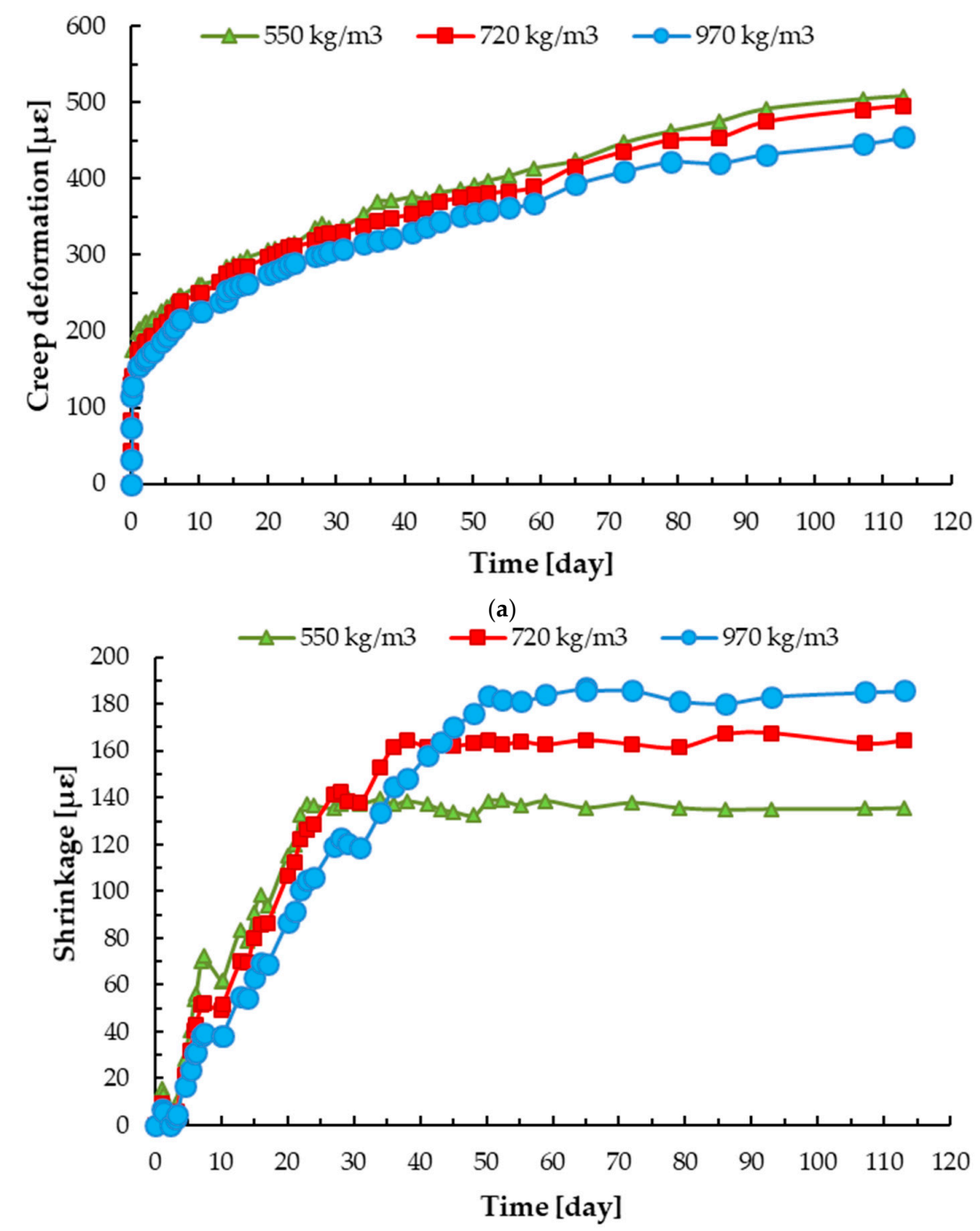

(b)

Figure 9. Relationship between creep deformation (a) and shrinkage (b) and time for foamed concrete with different densities.

The simultaneous measurement of shrinkage strains took place in concrete for 30 to 50 days of measurement for foamed concrete with a density of around $500-1000 \mathrm{~kg} / \mathrm{m}^{3}$; see Figure $9 \mathrm{~b}$. It can be observed that for samples with lower density, drying shrinkage was completed earlier. Moreover, for foamed concrete with a higher density, greater drying shrinkage was obtained. The presented values are relatively small, because the presented shrinkage was investigated after 28 days of hardening for foamed concrete with a density of around $500-1000 \mathrm{~kg} / \mathrm{m}^{3}$. Drying shrinkage of foamed concrete was relatively high. It was found to be 4 to 10 times higher than normal concrete due to the aggregate type in the mix design, higher cement and water content and mineral admixture in foamed concrete [8]. It is reported that the drying shrinkage on day 60 was $2450 \mu \varepsilon$ for foamed concrete with a density of $1600 \mathrm{~kg} / \mathrm{m}^{3}$, which was made of Portland cement (type I), water $\left(w_{e f f} / c=0.5\right)$ and sand [22]. For the same density of foamed concrete, but made of CEM I 52.5 Portland cement, water $\left(w_{\text {eff }} / c=0.43\right)$ and ground granulated blast-furnace slag, Wan et al. [82] obtained a drying shrinkage of around $2000 \mu \varepsilon$ was observed. Sun et al. [75] determined that the drying shrinkage of foamed concrete (CEM II 52.5 Portland cement and water with $w_{\text {eff }} / \mathrm{c}$ ratio of 0.5 ) with a density of around $600 \mathrm{~kg} / \mathrm{m}^{3}$ on day 90 was 
from 2500 to $3020 \mu \varepsilon$ depending on the type of foaming agent used. Meanwhile, drying shrinkages of normal concrete are reported to be between 200 and $800 \mu \varepsilon$ [85], and for mortar, between 800 and $2000 \mu \varepsilon$ [86].

Drying shrinkage can be modified by selecting a suitable foaming agent type at an appropriate volume [12,87], although research carried out by Sun et al. [75] reported that drying shrinkage is slightly dependent on the origin of the foaming agent [75]. However, Wan et al. [82] determined that it depends on the hardening conditions. Meanwhile, Chindaprasirt and Rattanasak [22] demonstrated that drying shrinkage can be limited to 1520, 1430 and $1060 \mu \varepsilon$ with the addition of a chemical admixture.

\section{Conclusions}

The aim of the study was to assess the properties of foamed concrete made of a synthetic polymer foaming agent. This experimental work has included four different foaming agent contents (4.0, 5.0, 6.0 and $8.0 \mathrm{dm}^{3}$ per $100 \mathrm{~kg}$ of cement), and the results obtained foamed concrete with a target density of $500,700,800$ and $1000 \mathrm{~kg} / \mathrm{m}^{3}$ with a tolerance $\pm 50 \mathrm{~kg} / \mathrm{m}^{3}$. Based on the results of this experimental investigation, the following key conclusions can be drawn:

- The density of hardened foamed concrete was $970 \pm 30,800 \pm 30,720 \pm 20$ and $550 \pm 20 \mathrm{~kg} / \mathrm{m}^{3}$ for foaming agent content of 4.0, 5.0, 6.0 and $8.0 \mathrm{dm}^{3}$ per $100 \mathrm{~kg}$ of cement, respectively. The volume of foam commonly created air-voids and resulted in lower density.

- The differences between the density of the mixture and the density of the hardened sample were up to $170 \mathrm{~kg} / \mathrm{m}^{3}$ depending on the density of foamed concrete samples; larger differences were demonstrated for higher densities. In this way, the difference between the density of the mixture and the hardened foamed concrete was obtained in order to design the mixture with the target parameters.

- Foamed concrete with a density of 700 and $800 \mathrm{~kg} / \mathrm{m}^{3}$ had similar characteristics of pores, such as number, area, perimeter and shape descriptors (circularity, roundness and solidity). It can be observed that the size of pores was from 0.26 to even $3.45 \mathrm{~mm}$ for foamed concrete with a density of $700 \mathrm{~kg} / \mathrm{m}^{3}$, while the average size of pores for foamed concrete with a density of $500 \mathrm{~kg} / \mathrm{m}^{3}$ was from 0.43 to $0.65 \mathrm{~mm}$.

- The number of air-voids for foamed concrete with a density of $500 \mathrm{~kg} / \mathrm{m}^{3}$ was greater and the average thickness of air bubbles wall was thinner than for the other densities.

- Specimens with a density of around 700 and $800 \mathrm{~kg} / \mathrm{m}^{3}$ had smaller air-voids, but more large air bubbles up to $3.5 \mathrm{~mm}$ in diameter were observed by higher density.

- With the addition of foaming agent of $8.0,6.0,5.0$ and $4.0 \mathrm{dm}^{3}$ per $100 \mathrm{~kg}$ of cement, the compressive strength was equal to $5.9 \pm 0.2,5.1 \pm 0.2,3.8 \pm 0.3$ and $1.4 \pm 0.2 \mathrm{MPa}$, respectively. The obtained compressive strengths were higher than those found in the literature for the same densities. This was most likely related to the fact that the synthetic foaming agent contained a stabilizer foam.

- With increasing density of foamed concrete, smaller creep deformations were obtained. Creep deformations were 509, 495 and $455 \mu \varepsilon$ for samples with density of around 500, 700 and $1000 \mathrm{~kg} / \mathrm{m}^{3}$. Deformation under long-term loading took place up to 90 days, regardless of the density of the foamed concrete.

Author Contributions: Conceptualization, M.K.; Data Curation, M.K.; Formal analysis, M.K.; Funding Acquisition, M.K.; Investigation, M.K., A.K. and M.M.; Methodology, M.K. and A.K.; Project Administration, M.K.; Resources, M.K.; Supervision, M.K.; Validation, M.K.; Visualization, M.K. and M.M.; Writing-Original Draft Preparation, M.K.; Writing-Review and Editing, M.K. All authors have read and agreed to the published version of the manuscript.

Funding: This work was supported by the ongoing research project entitled "Stabilization of weak soil by application of layer of foamed concrete used in contact with subsoil" (LIDER/022/537/L-4/NCBR/2013) financed by the National Centre for Research and Development within the LIDER Program. 
Acknowledgments: Thanks are extended to the Faculty of Civil Engineering of the Silesian University of Technology for carrying out shrinkage and creep tests on request. The authors would like to thank Prof. Lech Czarnecki for the initial verification of the text of the article.

Conflicts of Interest: The authors declare no conflict of interest.

\section{References}

1. Zhang, X.-P.; Cheng, X.-M. Energy consumption, carbon emissions, and economic growth in China. Ecol. Econ. 2009, 68, 2706-2712. [CrossRef]

2. Arouri, M.E.H.; Youssef, A.B.; M'henni, H.; Rault, C. Energy consumption, economic growth and $\mathrm{CO}_{2}$ emissions in Middle East and North African countries. Energy Policy 2012, 45, 342-349. [CrossRef]

3. Jaunky, V.C. The $\mathrm{CO}_{2}$ emissions-income nexus: Evidence from rich countries. Energy Policy 2011, 39, 1228-1240. [CrossRef]

4. Lapinskienè, G.; Peleckis, K.; Slavinskaite, N. Energy consumption, economic growth and greenhouse gas emissions in the European Union countries. J. Bus. Econ. Manag. 2017, 18, 1082-1097. [CrossRef]

5. Sterpu, M.; Soava, G.; Mehedintu, A. Impact of Economic Growth and Energy Consumption on Greenhouse Gas Emissions: Testing Environmental Curves Hypotheses on EU Countries. Sustainability 2018, 10, 3327. [CrossRef]

6. European Commission (CE). Energy Roadmap 2050 Impact Assessment and Scenario Analysis. 2011. Available online: https://ec.europa.eu/energy/sites/ener/files/documents/roadmap2050_ia_20120430_en_0.pdf (accessed on 27 September 2020).

7. Pan, Z.; Li, H.; Liu, W. Preparation and characterization of super low density foamed concrete from Portland cement and admixtures. Constr. Build. Mater. 2014, 72, 256-261. [CrossRef]

8. Amran, Y.H.M.; Farzadnia, N.; Ali, A.A.A. Properties and applications of foamed concrete: A review. Constr. Build. Mater. 2015, 101, 990-1005. [CrossRef]

9. Nambiar, E.K.; Ramamurthy, K. Air-void characterization of foam concrete. Cem. Concr. Res. 2007, 37, 221-230. [CrossRef]

10. Raj, A.; Sathyan, D.; Mini, K.M. Physical and functional characteristics of foam concrete: A review. Constr. Build. Mater. 2019, 221, 787-799. [CrossRef]

11. Fu, Y.; Wang, X.; Wang, L.; Li, Y. Foam concrete: A state-of-the-art and state-of-the-practice review. Adv. Mater. Sci. Eng. 2020, 2020, 6153602. [CrossRef]

12. Ramamurthy, K.; Nambiar, E.K.; Ranjani, G.I.S. A classification of studies on properties of foam concrete. Cem. Concr. Compos. 2009, 31, 388-396. [CrossRef]

13. Dhir, R.K.; Newlands, M.D.; McCarthy, A. Use of Foamed Concrete in Construction: Proceedings of the Conference Held at the University of Dundee, Scotland, UK, on 5 July 2005; Thomas Telford: Dundee, UK, 2005.

14. Hilal, A.A.; Thom, N.H.; Dawson, A.R. On entrained pore size distribution of foamed concrete. Constr. Build. Mater. 2015, 75, 227-233. [CrossRef]

15. Alonge, O.R.; Mahyuddin, R. Experimental production of sustainable lightweight foamed concrete. Br. J. Appl. Sci. Technol. 2013, 3, 994-1005. [CrossRef]

16. Hajimohammadi, A.; Ngo, T.; Mendis, P. Enhancing the strength of pre-made foams for foam concrete. Cem. Concr. Compos. 2018, 87, 164-171. [CrossRef]

17. Dissanayake, D.M.K.W.; Jayasinghe, C.; Jayasinghe, M.T.R. A comparative embodied energy analysis of a house with recycled expanded polystyrene (EPS) based foam concrete wall panels. Energy Build. 2017, 135, 85-94. [CrossRef]

18. Zahari, N.M.; Rahman, I.A.; Zaidi, A.M.A. Foamed concrete: Potential application in thermal insulation. In Proceedings of the MUCEET2009 Malaysian Technical Universities Conference on Engineering and Technology, MS Garden, Kuantan, Malaysia, 20-22 June 2009; pp. 47-52. Available online: https://pdfs.semanticscholar.org/f952/c92c86ca2bbee2d282a269d25f6f75732eab.pdf?_ga=2.162112444. 160126985.1586034381-204925583.1582726913 (accessed on 27 September 2020).

19. Huang, Z.; Zhang, T.; Wen, Z. Proportioning and characterization of Portland cement-based ultra-lightweight foamed concretes. Constr. Build. Mater. 2015, 79, 390-396. [CrossRef]

20. Zhang, Z.; Provis, J.I.; Reid, A.; Wang, H. Mechanical, thermal insulation, thermal resistance and acoustic absorption properties of geopolymer foam concrete. Cem. Concr. Compos. 2009, 62, 97-105. [CrossRef] 
21. Kearsley, E.P.; Wainwright, P.J. The effect of porosity on the strength of foamed concrete. Cem. Concr. Res. 2002, 32, 233-239. [CrossRef]

22. Chindaprasirt, P.; Rattanasak, U. Shrinkage behavior of structural foam lightweight concrete containing glycol compounds and fly ash. Mater. Des. 2011, 32, 723-727. [CrossRef]

23. Cox, L.S.; Van Djijk, S. Foam concrete: A different kind of mix. Concrete 2002, 36, 54-55.

24. Weigler, H.; Karl, S. Structural lightweight aggregate concrete with reduced density—Lightweight aggregate foamed concrete. Int. J. Cem. Comp. Light. Concr. 1980, 2, 101-104. [CrossRef]

25. Mydin, M.A.O.; Wang, Y.C. Structural performance of lightweight steel-foamed concrete-steel composite walling system under compression. Thin-Wall. Struct. 2011, 49, 66-76. [CrossRef]

26. Jones, M.R.; McCarthy, A. Preliminary views on the potential of foamed concrete as a structural material. Mag. Concr. Res. 2005, 57, 21-31. [CrossRef]

27. Amran, Y.H.M.; Ali, A.A.A.; Rashid, R.S.M.; Hejazi, F.; Safiee, N.A. Structural behavior of axially loaded precast foamed concrete sandwich panels. Constr. Build. Mater. 2016, 107, 307-320. [CrossRef]

28. Fadila, R.; Suleiman, M.Z.; Noordin, N.M. Paper fiber reinforced foam concrete wall paneling system. In Proceedings of the 2nd International conference on built environment in developing countries (ICBEDC 2008), Penang, Malaysia, 3-4 December 2008; Available online: https://pdfs.semanticscholar.org/7101/ 7e911ed728bc645ebb829db413cdf0ed5648.pdf (accessed on 27 September 2020).

29. Kang, J. Composite and non-composite behaviors of foam-insulated concrete sandwich panels. Compos. Part B Eng. 2015, 68, 153-161. [CrossRef]

30. Fernando, P.L.N.; Jayasinghe, M.T.R.; Jayasinghe, C. Structural feasibility of Expanded Polystyrene (EPS) based lightweight concrete sandwich wall panels. Constr. Build. Mater. 2017, 139, 45-51. [CrossRef]

31. Portal, N.W.; Flansbjer, M.; Zandia, K.; Wlasak, L.; Malaga, K. Bending behaviour of novel Textile Reinforced Concrete-foamed concrete (TRC-FC) sandwich elements. Comp. Struct. 2017, 177, 104-118. [CrossRef]

32. Rum, R.H.M.; Jaini, Z.M.; Abd Ghafar, N.H.; Abd Rahman, N. A preliminary experimental study on vibration responses of foamed concrete composite slabs. IOP Conf. Ser. Mater. Sci. Eng. 2017, 271, 12102. [CrossRef]

33. Fedorowicz, L.; Kadela, M. Foamed concrete used a subbase for some systems structure-subsoil. In Proceedings of the 7th Congress Inžinierska Geológia 2012 Engineering Geology 2012, Nový Smokovec, Slovakia, 14-15 June 2012.

34. Kadela, M.; Kozłowski, M.; Kukiełka, A. Application of foamed concrete in road pavement-weak soil system. Proc. Eng. 2017, 193, 439-446. [CrossRef]

35. Kadela, M.; Kozłowski, M. Foamed concrete layer as sub-structure of industrial concrete floor. Proc. Eng. 2016, 161, 468-476. [CrossRef]

36. Drusa, M.; Fedorowicz, L.; Kadela, M.; Scherfel, W. Application of geotechnical models in the description of composite foamed concrete used in contact layer with the subsoil. In Proceedings of the 10th Slovak Geotechnical Conference-Geotechnical Problems of Engineering Constructions, Bratislava, Slovakia, 30-31 May 2011.

37. Decký, M.; Drusa, M.; Zgútová, K.; Blaško, M.; Hájek, M.; Scherfel, W. Foam concrete as new material in road constructions. Proc. Eng. 2016, 161, 428-433. [CrossRef]

38. Vlcek, J.; Drusa, M.; Scherfel, W.; Sedlar, B. Experimental Investigation of properties of foam concrete for industrial floors in testing field. IOP Conf. Ser. Earth Environ. Sci. 2017, 95, 22049. [CrossRef]

39. Tian, W.; Li, L.; Zhao, X.; Zhou, M.; Wamg, N. Application of foamed concret in road engineering. In Proceedings of the International Conference on Transportation Engineering ICTE 2009, Chengdu, China, 25-27 July 2009.

40. Lee, Y.L.; Goh, K.S.; Koh, H.B.; Ismail, B. Foamed aggregate pervious concrete-an option for road on peat. In Proceedings of the Malaysian Technical Universities Conference on Engineering and Technology (MUCEET 2009), MS Garden, Kuantan, Malaysia, 20-22 June 2009.

41. Pokorska-Silva, I.; Kadela, M.; Fedorowicz, L. A reliable numerical model for assessing the thermal behavior of a dome building. J. Build. Eng. 2020, 32, 101706. [CrossRef]

42. Awang, H.; Al-Mulali, M. Strength of sieved only oil palm ash foamed concrete. Int. J. Eng. Technol. 2016, 8, 354-357. [CrossRef]

43. Wu, H.C.; Sun, P. New building materials from fly ash-based lightweight inorganic polymer. Constr. Build. Mater. 2007, 21, 211-217. [CrossRef] 
44. Sarmin, S.N. Lightweight Building Materials of Geopolymer Reinforced Wood Particles Aggregate-A Review. Appl. Mech. Mater. 2015, 802, 220-224. [CrossRef]

45. Neville, A.M. Properties of Concrete, 2nd ed.; Pitman: London, UK, 1973.

46. Li, T.; Huang, F.; Zhu, J.; Tang, J.; Liu, J. Effect of foaming gas and cement type on the thermal conductivity of foamed concrete. Constr. Build. Mater. 2020, 231, 117197. [CrossRef]

47. Ma, C.; Chen, B. Experimental study on the preparation and properties of a novel foamed concrete based on magnesium phosphate cement. Constr. Build. Mater. 2017, 137, 160-168. [CrossRef]

48. Ghorbani, S.; Ghorbani, S.; Tao, Z.; de Brito, J.; Tavakkolizadeh, M. Effect of magnetized water on foam stability and compressive strength of foam concrete. Constr. Build. Mater. 2019, 197, 280-290. [CrossRef]

49. Ma, C.; Chen, B. Properties of foamed concrete containing water repellents. Constr. Build. Mater. 2016, 123, 106-114. [CrossRef]

50. Kearsley, E.P.; Wainwright, P.J. Porosity and permeability of foamed concrete. Cem. Concr. Res. 2001, 31, 805-812. [CrossRef]

51. Oren, O.H.; Gholampour, A.; Gencel, O.; Ozbakkaloglu, T. Physical and mechanical properties of foam concretes containing granulated blast furnace slag as fine aggregate. Constr. Build. Mater. 2020, 238, 117774. [CrossRef]

52. Kolias, S.; Georgiou, C. The effect of paste volume and of water content on the strength and water absorption of concrete. Cem. Concr. Compos. 2005, 27, 211-216. [CrossRef]

53. Awang, H.; Mydin, M.A.O.; Farhan, R.A. Effect of additives on mechanical and thermal properties of lightweight foamed concrete. Adv. Appl. Sci. Res. 2012, 3, 3326-3338.

54. Hilal, A.A.; Thom, N.H.; Dawson, A.R. The Use of Additives to Enhance Properties of PreFormed Foamed Concrete. Int. J. Eng. Technol. 2015, 7. [CrossRef]

55. Pan, Z.; Hiromi, F.; Wee, T. Preparation of high performance foamed concrete from cement, sand and mineral admixtures. J. Wuhan Univ. Technol. 2007, 22, 295-298. [CrossRef]

56. Chen, B.; Liu, J. Experimental application of mineral admixtures in lightweight concrete with high strength and workability. Constr. Build. Mater. 2008, 22, 655-659. [CrossRef]

57. Kadela, M.; Kukiełka, A. Influence of foaming agent content in fresh concrete on elasticity modulus of hard foam concrete. In Proceedings of the 11th International Symposium on Brittle Matrix Composites BMC 2015, Warsaw, Poland, 12-14 October 2015; pp. 489-496.

58. Kearsley, E.P.; Wainwright, P.J. The effect of high fly ash content on the compressive strength of foamed concrete. Cem. Concr. Res. 2001, 31, 105-112. [CrossRef]

59. Kozłowski, M.; Kadela, M. Mechanical Characterization of Lightweight Foamed Concrete. Adv. Mater. Sci. Eng. 2018, 2018, 6801258. [CrossRef]

60. Kozlowski, M.; Kadela, M. Experimental and Numerical Investigation of Fracture Behavior of Foamed Concrete Based on Three-Point Bending Test of Beams with Initial Notch. In Proceedings of the ICMCME 2015: International Conference on Mechanical, Civil and Material Engineering, Barcelona, Spain, 17-18 August 2015; p. 943. [CrossRef]

61. Amran, Y.H.M.; Alyousef, R.; Alabduljabbar, H.; Khudhair, M.H.R.; Hejazi, F.; Alaskar, A.; Alrshoudi, A.; Siddika, A. Performance properties of structural fibred-foamed concrete. Res. Eng. 2020, 5, 100092. [CrossRef]

62. Zhu, H.; Chen, L.; Xu, J.; Han, Q. Experimental study on performance improvement of anionic surfactant foaming agent by xanthan gum. Constr. Build. Mater. 2020, 230, 116993. [CrossRef]

63. Ghorbani, S.; Sharifi, S.; de Brito, J.; Ghorbani, S.; Jalayer, M.A.; Tavakkolizadeh, M. Using statistical analysis and laboratory testing to evaluate the effect of magnetized water on the stability of foaming agents and foam concrete. Constr. Build. Mater. 2019, 207, 28-40. [CrossRef]

64. Kuzielová, E.; Pach, L.; Palou, M. Effect of activated foaming agent on the foam concrete properties. Constr. Build. Mater. 2016, 125, 998-1004. [CrossRef]

65. Falliano, D.; De Domenico, D.; Ricciardi, G.; Gugliandolo, E. Experimental investigation on the compressive strength of foamed concrete: Effect of curing conditions, cement type, foaming agent and dry density. Constr. Build. Mater. 2018, 165, 735-749. [CrossRef]

66. Liu, X.; Wang, S.; Li, S.; Wang, J. Study on high-efficiency complexed foaming agent for lightweight foamed concrete. Adv. Mater. Res. 2011, 250-253, 569-573. [CrossRef] 
67. She, W.; Du, Y.; Miao, C.; Liu, J.; Zhao, G.; Jiang, J.; Zhang, Y. Application of organic- and nanoparticle-modified foams in foamed concrete: Reinforcement and stabilization mechanisms. Cem. Concr. Res. 2018, 106, 12-22. [CrossRef]

68. Czarnecki, L.; Łukowski, P. Polymer-cement concretes. Cem. Wapno Beton 2010, 15, 243-258.

69. Wang, R.; Li, J.; Zhang, T.; Czarnecki, L. Chemical interaction between polymer and cement in polymer-cement concrete. Bull. Pol. Acad. Sci. Tech. Sci. 2016, 64, 785-792. [CrossRef]

70. Zalegowski, K.; Piotrowski, T.; Garbacz, A. Influence of polymer modification on the microstructure of shielding concrete. Materials 2020, 13, 498. [CrossRef]

71. Panesar, D.K. Cellular concrete properties and the effect of synthetic and protein foaming agents. Constr. Build. Mater. 2013, 44, 575-584. [CrossRef]

72. Amran, Y.H.M.; Rashid, R.S.M.; Hejazi, F.; Safiee, N.A.; Ali, A.A.A. Response of precast foamed concrete sandwich panels to flexural loading. J. Build. Eng. 2016, 7, 143-158. [CrossRef]

73. Jiang, J.; Lu, Z.; Niu, Y.; Li, J.; Zhang, Y. Study on the preparation and properties of high-porosity foamed concretes based on ordinary Portland cement. Mater. Des. 2016, 92, 949-959. [CrossRef]

74. Chen, B.; Liu, N. A novel lightweight concrete-fabrication and its thermal and mechanical properties. Constr. Build. Mater. 2013, 44, 691-698. [CrossRef]

75. Sun, C.; Zhu, Y.; Guo, J.; Zhang, Y.; Sun, G. Effects of foaming agent type on the workability, drying shrinkage, frost resistance and pore distribution of foamed concrete. Constr. Build. Mater. 2018, 186, 833-839. [CrossRef]

76. Tan, X.; Chen, W.; Hao, Y.; Wang, X. Experimental study of ultralight $\left(<300 \mathrm{~kg} / \mathrm{m}^{3}\right)$ foamed concrete. Adv. Mater. Sci. Eng. 2014, 2014, 514759. [CrossRef]

77. Kozłowski, M.; Kadela, M.; Kukiełka, A. Fracture energy of foamed concrete based on three-point bending test on notched beams. Proc. Eng. 2015, 108, 349-354. [CrossRef]

78. Kadela, M.; Kozłowski, M. Degradation analysis of notched foam concrete beam. Appl. Mech. Mater. 2015, 797, 96-100. [CrossRef]

79. Kozłowski, M.; Kadela, M. Combined Experimental and Numerical Study on Fracture Behaviour of Low-Density Foamed Concrete. IOP Conf. Ser. Mater. Sci. Eng. 2018, 324, 12031. [CrossRef]

80. Yu, W.; Liang, X.; Ni, F.M.-W.; Oyeyi, A.G.; Tighe, S. Characteristics of Lightweight Cellular Concrete and Effects on Mechanical Properties. Materials 2020, 13, 2678. [CrossRef]

81. Waheed, A.; Arshid, M.U.; Mehboob, S.; Ahmed, A.; Sultan, T. Preparation of low-cost foam concrete using detergent. Tech. J. 2019, 24, 1-7.

82. Wan, K.T.; Zhu, H.; Yuen, T.Y.P.; Chen, B.; Hu, C.; Leung, C.K.Y.; Kuang, J.S. Development of low drying shrinkage foamed concrete and hygro-mechanical finite element model for prefabricated building fasçade applications. Constr. Build. Mater. 2018, 165, 939-957. [CrossRef]

83. Castillo-Lara, J.F.; Flores-Johnson, E.A.; Valadez-Gonzalez, A.; Herrera-Franco, P.J.; Carrillo, J.G.; Gonzalez-Chi, P.I.; Li, Q.M. Mechanical Properties of Natural Fiber Reinforced Foamed Concrete. Materials 2020, 13, 3060. [CrossRef]

84. Gonzenbach, U.T.; Studart, A.R.; Tervoort, E.; Gauckler, L.J. Stabilization of foams with inorganic colloidal particles. Langmuir 2006, 22, 10983-10988. [CrossRef]

85. Zia, P.; Ahmad, S.; Leming, M. High-Performance Concretes, a State-of-Art Report (1989-0994); FHWA-RD-97-030; Federal Highway Administration: McLean, VA, USA, 1997.

86. American Concrete Institute. Report on Factors Affecting Shinkage and Creep of Hardened Concrete; ACI 209.1R-05; American Concrete Institute: Farmington Hills, MI, USA, 2005.

87. Nambiar, E.K.; Ramamurthy, K. Shrinkage behawior of foam concrete. J. Mater. Civ. Eng. 2009, 21, 631-636. [CrossRef]

Publisher's Note: MDPI stays neutral with regard to jurisdictional claims in published maps and institutional affiliations.

(C) 2020 by the authors. Licensee MDPI, Basel, Switzerland. This article is an open access article distributed under the terms and conditions of the Creative Commons Attribution (CC BY) license (http://creativecommons.org/licenses/by/4.0/). 